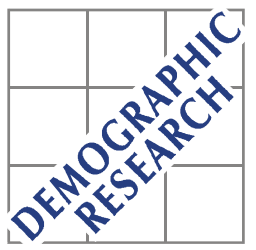

Demographic Research a free, expedited, online journal of peer-reviewed research and commentary in the population sciences published by the Max Planck Institute for Demographic Research Konrad-Zuse Str. 1, D-18057 Rostock · GERMANY www.demographic-research.org

DEMOGRAPHIC RESEARCH

SPECIAL COLLECTION 1, ARTICLE 11

PUBLISHED 19 September 2003, PAGES 349-372

www.demographic-research.org/special/1/11/

DOI: 10.4054/DemRes.2003.S1.11

Research Article

"My Girlfriends Could Fill

A Yanu-Yanu Bus":

Rural Malawian Men's Claims

About Their Own Serostatus

\title{
Amy Kaler
}

This special collection is edited by Susan Watkins, Eliya M. Zulu, Hans-Peter Kohler and Jere Behrman. The papers in this special collection were presented at the conference "Research on Demographic Aspects of HIV/AIDS in Rural Africa", held at the Population Studies Center, University of Pennsylvania, October 28, 2002.

(C) 2003 Max-Planck-Gesellschaft. 


\section{Table of Contents}

1 Introduction $\quad 350$

2 Methods and setting 351

$3 \quad$ Local knowledge about AIDS 355

$4 \quad$ Autobiographical diagnosis 358

$5 \quad$ HIV-positive status and masculinity 361

$6 \quad$ Serostatus belief and sexual behaviour $\quad 364$

7 Conclusions 366

$\begin{array}{ll}\text { Notes } & 368\end{array}$

$\begin{array}{ll}\text { References } & 370\end{array}$ 
Research Article

\title{
"My Girlfriends Could Fill A Yanu-Yanu Bus": Rural Malawian Men's Claims About Their Own Serostatus
}

\author{
Amy Kaler ${ }^{1}$
}

\begin{abstract}
In this paper, I investigate the ways that young men in rural southern Malawi talk about HIV and their own perceptions of risk. I relate these findings first to evolving gender relations in Malawi during the AIDS epidemic, and second to HIV prevention measures, with specific recommendations for changes in existing prevention campaigns.

I make three claims in this paper: first, that an unknown proportion of sexually active young men say that they are already HIV-positive, in the absence of any medical evaluation or any signs of AIDS; second, that men's claims to be HIV-positive emerge from a particular configuration of masculinity as well as from personal conviction; and third, that this belief is used to justify continuing risky sexual behaviour, such as having multiple partners or not using condoms, on the grounds that this behaviour is no longer dangerous if one has already contracted the virus.

This paper is based on observational journals kept by local research assistants in which they recorded mentions of AIDS in informal conversations which they overheard or participated in. I discuss the advantages and disadvantages of this classically anthropological methodology, as distinct from the more survey methods more standard in demography.
\end{abstract}

$1 \quad$ University of Alberta. E-mail: amy.kaler@ualberta.ca 


\section{Introduction}

Twenty years into the HIV epidemic, the gendered nature of AIDS is beyond dispute. Scores of researchers, writers and activists have made it clear that the AIDS epidemic is driven in large part by social constructions of gender which emphasize men's dominance over women (see e.g. Farmer 1994, Farmer, Connors and Simmons 1996, Long and Ankrah 1996, du Guerny and Sjoberg 1999, Schneider and Stoller 1997, Bond and Dover 1997, Renaud 1997, Setel 1999). However, most gendered approaches to AIDS treat the concept of gender in a rather narrow sense, as a relation of power between women and men which results in the subordination of the former to the latter. Gender in the sense of personal identity, a constantly-evolving set of beliefs and actions linked to awareness of sex differences, has not received the same sort of attention. In addition, most work on the gendering of AIDS has focused on women's experiences rather than men's, perhaps an extension of the common bias in social science research that women are gendered, but men are simply men.

In this paper, I intend to address both those gaps through studying the claims made by young Malawian men about their own serostatus, especially claims to be HIVpositive; and by locating these claims within the context of evolving ideas about masculinity in rural Malawi (Note 1). This effort is worthwhile not only because it makes the social construction of gender more visible, but also because it adds to extant knowledge about why men continue to take risks in their sexual behaviour, nearly two decades after the arrival of HIV.

I make three claims in this paper: first, that an unknown proportion of sexually active young men say that they are already HIV-positive, in the absence of any medical evaluation or any signs of AIDS; second, that men's claims to be HIV-positive emerge from a particular configuration of masculinity as well as from personal conviction; and third, that this claim is used to justify continuing risky sexual behaviour, such as having multiple partners or not using condoms, on the grounds that this behaviour is no longer dangerous if one has already contracted the virus.

At the outset, I want to be clear about what I am not arguing in this paper. I do not argue that Malawian men want to get AIDS. Similarly, I do not argue that the men in this paper "really" think that they are HIV-positive (indeed, I claim at the end of this paper that the notion of a fixed, internally consistent belief about one's own serostatus is a chimera). I cannot know what these men believe in their hearts; I can only know what they say, and it is the fact of that saying - that act of claims-making - that is the focus of this paper. Why do men make these claims, which on the surface seem bizarre? And what does the fact of this claims-making say about evolving ideas about both HIV and about masculinity itself? 
Men's belief that they are HIV-positive is linked to a particular conception of how AIDS works - specifically, the idea that HIV infection is deterministic, so that exposure to the virus is virtually a $100 \%$ guarantee that one will eventually come down with AIDS. This model of AIDS is reinforced by AIDS education and health promotion activities which stress the deadliness of AIDS and the fact that one can become HIVpositive after only one or very few exposures, such as encounters with commercial sex workers or with women with multiple partners. While this message is intended to scare people off risky behaviour by emphasizing their vulnerability, I believe it has also had the unintended consequence of strengthening the belief that if one has had some risky encounters in the past (as almost all young men have), then one is virtually certain to have contracted HIV and thus need not take any future protective measures. In this paper, I explore what men say about their beliefs about their serostatus, and how they link these beliefs to their actions.

\section{Methods and setting}

I arrive at these ends using methods which are unusual for demographers. Demographic research in general, and research on AIDS in particular, relies heavily on survey and questionnaire methods. While these methods have the virtues of producing quantifiable and comparable data, many aspects of social life cannot be captured within the pre-set categories which define the range of knowledge in survey instruments. Because some of the ideas and concepts which are crucial to behaviour change can't be captured in standard ways, when the Malawi Diffusion and Ideational Change Project (MDICP) sought to gauge whether Malawians were likely to change their individual behaviour in response to the threat of AIDS, we also used observational journals, kept by young men and women who worked for MDICP, in which they wrote down every conversation, casual chat, or passing reference about AIDS which they could recall in the course of their daily lives. While both men and women talked extensively about AIDS-related matters in their casual conversation, only men talked about their own sexual behaviours and their implications for HIV. Women's mentions of AIDS took the form of worrying about their own or their relatives' vulnerability, deploring the impact of AIDS on community and family, and discussing the prospects of acquaintances and family members who were thought to have AIDS. Sexual agency, especially sexual agency outside of marriage, rarely surfaced in the journals kept by women (although it did surface in interviews with women by MDIC researchers, see Tawfik 2003, Tawfik and Watkins 2003). Thus, for this paper, our analysis is confined to men (Note 2).

This study was conducted in Balaka district in rural southern Malawi, in the area triangulated by the towns of Liwonde and Balaka and the trading center Ulongwe. This 
site is referred to as "southern" in MDICP terminology. This is a fairly typical Malawian rural area - extended families live in loosely-connected groups of homesteads, formed into villages, relying mainly on subsistence farming and some selling of tobacco and cotton. The area borders one of the main roads in the country, which feeds into the nearby cities of Zomba and Blantyre, two hours away by public transit. Many of the younger adults travel to and from the city looking for work or excitement. To the northeast is the port of Mangochi on Lake Malawi, a major centre for small-scale fishing and fish-trading, with a reputation as the local red-light district.

This research was carried out as part of the much larger Malawi Diffusion and Ideational Change Project, headed by co-investigators Susan Cotts Watkins, Hans-Peter Kohler and Jere Behrman of the University of Pennsylvania and Eliya Zulu of the African Population Research Centre. The main work of the MDICP has been carrying out large-scale surveys and smaller-scale qualitative inquiries into changing attitudes to family planning and HIV-related behaviour in three sites corresponding to Malawi's three provinces (Watkins et al. 2003).

The national AIDS prevalence in Malawi is estimated at $16 \%$, but the prevalence in southern province, where this study was done, is thought to be around 19\%. AIDS is now the leading cause of death for people aged 15 to 49 (Doctor 2002). Compared to other African countries with high prevalence rates such as Uganda or Zambia, the Malawian government's response to the pandemic has been low-key. In everyday life, most people encounter "official" AIDS education or prevention efforts in the form of spots on the radio, posters in local health clinics, Chishango ("shield") condoms for sale or distribution from tuckshops and some bars, and in some primary schools, the creation of "Edzi Toto" ("Stop AIDS") clubs, meant to disseminate AIDS information to youth. The content of these radio spots, posters and clubs is similar to that in AIDS-prevention programmes all over southern Africa, stressing the devastation AIDS wreaks on families and communities and the dangers of risky behaviour, especially sex with people known to be "promiscuous". Malawians are ambivalent about these AIDSprevention efforts: some see them as indecent because of the explicit information about sex and condoms which they contain, and others see them as yet another set of government directives telling people what they must do (Mtika 2001:12-13).

In addition to this official "AIDS awareness", people attend funerals of relatives or acquaintances on average three times per month (Watkins, personal communication). If the deceased was part of the "AIDS group" - young, reasonably well-off, sexually active - speculation about the cause of death runs high. AIDS is the stuff of rumours and gossip: who is sure to have AIDS, who is likely to have it, who has divorced their husband or wife because of suspected AIDS, who is putting their spouse at risk of AIDS through their behaviour, and so on. While some people, mainly the elderly, claim that AIDS is being over-diagnosed and that all sorts of innocuous illnesses are now 
being attributed to AIDS, for most people, AIDS is omnipresent. It may seem, indeed, that AIDS is the inevitable fate of anyone who has sex with more than one partner in Balaka district in the $21^{\text {st }}$ century.

Epidemiological research, however, suggests that AIDS is not the inevitable result of sex. The Rakai Project in rural Uganda, a very similar setting to rural Malawi, found a transmission rate per act with an infected partner to be $0.11 \%$, or one transmission for every thousand sex acts (Note 3, Gray et al. 2001, cited in Hollander 2001; see also Quinn et al. 2000 and World Bank 1999:59). In other words, the vast majority of sex acts with infected partners in rural Africa do not result in AIDS transmission. Thus, although AIDS and its consequences are evident everywhere, the majority of Malawians are not HIV-positive, even those who may have had infected partners. In rural Malawi, however, virtually no one knows his or her actual serostatus.

In order to collect comments about HIV/AIDS, the MDICP asked five skilled research assistants to keep informal journals - notebook in which they would record "everything that you hear people say about AIDS". The data included conversations in which the research assistants participated as well as conversations they overheard, in both public settings such as a bus station or a bar, and private settings such as a home. The journalists were asked to record as accurately and in as much detail as possible. Depending on the journalists, the degree of detail varied from verbatim scripts of overheard conversation, complete with elaborate descriptions of the setting, to summary paragraphs. Journalists did not tell their conversation partners that they were taking mental notes for journal entries, and were asked not to instigate any conversations about AIDS by themselves (Note 4). The journals therefore consist of "natural discourse", drawn from spontaneous settings (Note 5, Farmer 1994).

Journalists used standard school exercise books for their journals, and when each exercise book was full, it was sent either to a friend of one of the researchers who lived in Blantyre or directly to the MDICP in Philadelphia. In Philadelphia the journals were transcribed into Word files, and these were coded and analyzed with Ethnograph software. At present, we have 150 journals extending from 1999 to 2003. Journals are still being kept by the journalists and sent to Philadelphia.

This methodology has its advantages and its drawbacks. Chief among the advantages is that the journals present ideas, concepts and beliefs in the very process of circulation, away from the artificial structures of the interview situation (Note 6). Data from the journals is therefore free from "interview effects", including the very common tendency for interview respondents to give a "correct" answer rather than a true one. In addition, because there are no pre-set categories for responses, the journal method opens up new areas of knowledge and new lines of inquiry, as opposed to confirming or disconfirming the theories of researchers. Finally, through the journals we hear the voices of those who are not often represented in surveys and standard interviews - the 
extremely old, the extremely young, the disaffected and the transient. Our five journalists are all very different people, with very different social (and geographic) locations and personal networks; thus when certain themes came up over and over in the journals, I could be fairly confident that these themes represent fairly widely voiced ideas; or at least ideas which were widely voiced within Balaka at that point (Note 7).

The journal method also has its disadvantages. Unlike survey data, journal data is difficulty to quantify and thus difficult to use in temporal or spatial comparisons. In addition, I am not so naïve as to assume that the journalists wrote down absolutely everything they heard which was in any way related to AIDS, without filtering or subtly (and perhaps unconsciously) altering the content of their observations. The extent and effects of this filtering are unknown. Judging by the content of the journals, however, the journalists did not shy away from including material which showed them and their personal networks in a less than flattering light - for example, one journalist wrote about his wife accusing him of extramarital affairs, while another wrote about her cousin's callous treatment of a brother who was sick with AIDS. Second, it is difficult to estimate the prevalence of AIDS talk among men relative to other pressing topics. Given that the journals contain information on AIDS and family planning religion exclusively, it is difficult to know whether this is a major preoccupation of Malawian men, a minor one or somewhere in between. Given the swath that AIDS is cutting through Malawian communities, however, it is reasonable to think that that AIDS is frequently on men's minds and in their conversations.

Also, while our sample of conversations about AIDS is very diverse, I do not know whether it is truly representative of the population. Whether or not our sample is representative, however, it is very heterogeneous, and that heterogeneity itself makes it valuable for generating knowledge about what people think of AIDS.

Finally I have no guarantee that what the journalists wrote down actually occurred, in other words that they didn't just make up their journals. The five journalists have been working for the Malawi Diffusion and Ideational Change project since 1998 as surveyors, and were chosen because they had proven to be the most reliable, enthusiastic and insightful of the MDICP surveyors. I was therefore willing to take their work on trust. In addition, on a purely subjective level, the journals have a quality of verisimilitude which is difficult, if not impossible, to fake. Although certain themes came up again and again, clichéd situations and characters rarely did. Given the diversity and range of the journals, it would probably have been more work to invent all the situations and conversations than to simply record them. 
Table 1: $\quad$ Journalists 1999-2001 (Note 4)

\begin{tabular}{|c|c|c|c|c|c|c|}
\hline Name & Sex & Age & $\begin{array}{l}\text { Marital } \\
\text { status }\end{array}$ & Occupation & $\begin{array}{l}\text { Economic } \\
\text { status }\end{array}$ & Other \\
\hline 'Alice' & $\mathrm{F}$ & Early 30 s & $\begin{array}{l}\text { Divorced, } \\
1 \text { child }\end{array}$ & Farmer & $\begin{array}{l}\text { Low- } \\
\text { middle }\end{array}$ & $\begin{array}{l}\text { Mainstay of extended } \\
\text { family, sole support of } 10\end{array}$ \\
\hline 'Sophie' & $\mathrm{F}$ & Mid-20s & $\begin{array}{l}\text { Married } \\
\text { during } \\
\text { course of } \\
\text { project }\end{array}$ & Housewife & High & $\begin{array}{l}\text { From local landowning } \\
\text { family, married soldier and } \\
\text { moved to army base in } \\
\text { town }\end{array}$ \\
\hline 'Simon' & M & Early $20 \mathrm{~s}$ & $\begin{array}{l}\text { Married, } \\
2 \text { children }\end{array}$ & $\begin{array}{l}\text { Peasant } \\
\text { farmer/fish } \\
\text { trader }\end{array}$ & $\begin{array}{l}\text { Low- } \\
\text { middle }\end{array}$ & $\begin{array}{l}\text { Although married, } \\
\text { socializes extensively with } \\
\text { young single men }\end{array}$ \\
\hline 'Derek' & M & Mid-30s & Married & $\begin{array}{l}\text { Village } \\
\text { health } \\
\text { assistant }\end{array}$ & $\begin{array}{l}\text { High- } \\
\text { middle }\end{array}$ & $\begin{array}{l}\text { Runs educational } \\
\text { programs in villages } \\
\text { promoting preventive } \\
\text { health }\end{array}$ \\
\hline 'Diston' & M & Mid-20s & Single & $\begin{array}{l}\text { Peasant } \\
\text { farmer/day } \\
\text { labourer in } \\
\text { town }\end{array}$ & $\begin{array}{l}\text { Low- } \\
\text { middle }\end{array}$ & $\begin{array}{l}\text { Divides time between town } \\
\text { and village, travels to } \\
\text { Zimbabwe for work }\end{array}$ \\
\hline 'Michael' & M & Early $20 \mathrm{~s}$ & Single & $\begin{array}{l}\text { Student in } \\
\text { large town }\end{array}$ & $\begin{array}{l}\text { High- } \\
\text { middle }\end{array}$ & $\begin{array}{l}\text { Dresses well, socializes } \\
\text { with local elite }\end{array}$ \\
\hline
\end{tabular}

\section{Local knowledge about AIDS}

In an earlier paper, I catalogued the reasons that men gave for not changing their sexual behaviour despite their knowledge that AIDS was fatal and was common in their communities (Kaler 2002). These reasons include the belief that one's fate is ultimately in God's or Allah's hands and the belief that it is psychologically impossible or damaging to not have sex or to forego having sex "plain", without a condom, but the most complex reason for foregoing behaviour change was the claim that due to past misbehaviour, one is now already infected.

Malawians arrived at this claim through a combination of accurate and inaccurate knowledge about AIDS. These men's sexual behaviour, like most people's sexual behaviour, is not entirely consistent with their knowledge about sex and its 
consequences. Among men married to women aged 15 to 49 (the group from which the MDICP drew its survey sample), 35\% of sexually active men reported "higher risk sex" (defined as sex with a casual partner) during the last year, but of these men only 39\% reported using a condom (and given the desirability bias of underreporting high-risk sexual activity and overreporting condom use, there are likely to be more men having higher risk sex and fewer using condoms than is reported). This pattern of reported behaviour is at odds with their knowledge about HIV/AIDS. In the 2000 Malawi Demographic and Health Survey, 100\% of men aged 15-49 had heard of AIDS, and $62 \%$ were reported to have "no incorrect beliefs" about AIDS, based on a composite of common untruths about AIDS. 85\% knew that AIDS cannot be transmitted casually, through sharing food, and $72 \%$ and $77 \%$ volunteered that using a condom and abstaining from sex (respectively) could protect one from AIDS. This knowledge has been gained relatively recently, as in the 1992 DHS only 26\% of men volunteered condoms as a way to prevent AIDS and only $32 \%$ volunteered abstaining from sex (www.measuredhs.com/hivdata, September 25 2002)

Although Malawians have clearly learned a lot about AIDS, some local beliefs about the virulence of AIDS do not track with current biomedical knowledge. Two assumptions are often made about the ubiquity and transmissibility of HIV: first, that it is everywhere and will eventually kill everyone; and second, that AIDS is extremely infective and that if one has been exposed to the virus, one's days are numbered.

Concerning the first assumption, the journals are filled with comments, often with a religious or eschatological gloss, that AIDS signals the end of the world, or at least the destruction of everyone in Malawi. School boys, for example, complained to their teacher that they saw no point in working hard at schoolwork because "no one will remain alive in the coming five years" (Alice, journal June 4 2001). On a bus journey, the same journalist's seatmate informed her that "I know that we shall all die of AIDS and there is nobody who will not taste AIDS". Another passenger chimed in: "It seems that God wants to destroy the whole world through that disease. We shall all die with AIDS" (ibid.). At funerals of older relatives, mourners often expressed the sentiment that no one currently alive would survive to attain the age at which their relatives died everyone would now die young because of AIDS. One phrase, used so often that it seemed to be a cliché, was the assertion that "AIDS has come for human beings [interpreted as the human race], not for animals" - in other words, AIDS is targeted to destroy everyone.

In addition to painting AIDS as a holocaust which would kill everyone, many local people believed that HIV was highly infective, and that only one exposure was enough to guarantee that one would become HIV-positive. For instance, people in the journals gossiped about acquaintances who had spouses suspected of having AIDS and what would happen to the marriage if the other spouse found out. Reactions to this dilemma 
were mixed, with some people claiming that there was still time for the partner who showed no signs of AIDS to protect his or her life, either by using condoms or by divorcing and abandoning the infected partner. Others, however, said that nothing could be done - if one's partner had HIV, it was certain that the HIV had been transmitted. Interestingly, although reports from formal interviews indicated that respondents were divided as to whether the partner of an HIV-positive person would inevitably have AIDS themselves, when this subject came up in the informal conversations recorded by the journalists, opinion was firmly that AIDS was inevitable. For example, in the course of a casual family visit, Simon asked his in-law what he thought most couples did when one of them was suspected of being HIV-positive:

And then I asked my in-law, 'What do people do after noticing that his/her partner seems to have AIDS? He said, 'Some couples come to an end and for others the marriage continues.' And I asked, 'Do they use condoms then?' $\mathrm{He}$ said 'I don't think they use because it will just be a waste of time since both of them have contracted the disease.' (Simon, journal May 3 2002)

Another friend of Simon's, who claimed to be sure he had AIDS as a result of his sexual adventures on trading trips to South Africa, was even more explicit, saying that HIV was transmitted in the first moment of sexual contact:

"AIDS is quite different from other diseases like bilharzia, where it happens that one partner may have it and another may not. But AIDS is not like that, if a partner has it definitely you also have it, and you'll just be waiting to die." (Simon, journal May 21 2002)

Evidence of belief in the transmissibility of HIV also comes from the chief's court. The infectivity of HIV has recently becomes an issue in petitions for divorce, as suspicion of AIDS has come to figure more and more as a cause for ending a marriage. For instance, in one particular case, in which a man wanted to divorce his wife for her alleged infidelity with a man suspected of having AIDS, the bystanders who had gathered to observe the drama muttered among themselves that the divorce was surely too late to save the husband. They claimed that the divorcing man "was stupid to divorce his wife at that time because if he feared AIDS, the he already has it, so there was no point of divorcing the wife while you're already infected" (Michael, journal October 21 2001).

The infectivity of HIV was also used by a widow to defend her husband's reputation against the rumour that he had died of AIDS - if he had been HIV-positive, 
she argued, surely she too would be sick by now. Since she had no signs of AIDS, then her husband must not have had the disease either (Michael, journal October 21 2001).

In a context in which AIDS is believed to be both totalizing in its effect and highly infective, it is hardly surprising that men who have had one or more "risky" encounters may live with the assumption, voiced or not, that they have HIV already and are going to get AIDS. For a young man whose behaviour has at some point matched the behaviour depicted in anti-AIDS posters, it is much easier to imagine oneself HIVpositive than HIV-negative.

In addition to beliefs about the perniciousness and infectivity of AIDS, Malawians are also presented with a model of AIDS risk which stresses sex with casual partners as the way to get AIDS. The biomedical model, simplified for public education, coexists with older models of disease in rural Africa involving sin or the violation of taboo, but the discourse captured in the journals clearly suggests that the biomedical model linking AIDS with unsafe sex is dominant among young men. This model makes its way to rural Malawi in the form of educational materials: talks and presentations by health workers and radio spots, as well as posters.

These talks, presentations, radio spots and posters stress the indissolubility of the link between sex and AIDS, so that unsafe sex becomes an arrow pointing straight at AIDS infection, with no possibility of escaping unscathed. Men are depicted consorting with girlfriends as death lurks in the background, or as images of their future selves as walking skeletons drift in front of them. The progression from casual sex to eventual death from AIDS is portrayed as inevitable - in the world of AIDS education, every young man who hires a sex worker eventually dies; every bout of casual sex ends with another AIDS case added to the total. The fact that the vast majority of sexual contacts with HIV-positive people do not end in death is never mentioned, and indeed it is difficult to see how this biological reality could be worked into the materials without undermining the message of caution. However, by presenting the idea of HIV transmission as the inevitable accompaniment to sex, these materials may reinforce the sense that every man who has had risky encounters has contracted HIV. For the young men in southern Malawi, who do not have access to blood tests, measuring one's own behaviour against that which is known to be "bad" is the only way of trying to figure out whether one might be HIV-positive."

\section{Autobiographical diagnosis}

Young men clearly know that they have been "bad", in terms of risky behaviour, leading to their claims to be HIV-positive. Conversely, the claim to be HIV-positive means that one must have been "bad". However, those behaviours which are "bad" 
from a public health standpoint have an ambiguous symbolic loading for these young men. Outside the realm of health promotion, having multiple partners and having sex without condoms can also function as proof that one is a real man, virile and masculine. Claims to these behaviours are made in front of audiences which also serve as arbiters of individuals' social worth and self-esteem, consisting usually of small groups of other young men in "men's spaces", such as bars, beerhalls, or just hanging around public markets.

The journals are filled with accounts of men who say they are certain that they have HIV, based on their past behaviour which they now know to have been risky (Note 8). The behaviours associated with AIDS - long-distance travel, multiple sexual partners and commodified sex - are part of many, if not most, young men's lives, and based on these experience they perform an autobiographical diagnosis: I have lived in a risky way, thus I must have contracted HIV (Note 9). A few examples below:

Diston: What about Gift, what can you do in such a situation when you feel threatened to [worried about] contracting HIV/AIDS from your sexual partner?

Gift: $\quad$ As of me, I do think that I am already infected because I have slept with several women and there is nothing that I can do other than just proceeding with the affairs because I have already lost hope about my HIV status [because of] the women I have been sleeping with.

Diston: What kind of women were you sleeping with so that you lose hope?

Gift: The first point that makes me to lose hope is that I have been catching STIs and the second thing is that I had a sexual partner who was a bargirl at Lunzu, all these make me lose hope about my HIV status. (Diston, second journal received, June 2002).

Friend: I don't fear AIDS because I know that I have it already.

Diston: How do you know that you have got AIDS?

Friend: I have malaria and some coughs so I know that I have it.

Diston: Do you use condoms when [sleeping with] these bargirls?

Friend: What for, since I know that I am already infected?

Diston: How did you get the disease then?

Friend: I got it from the same bargirls.

Diston: Why don't you just stop [sleeping with] them? 
Friend: $\quad$ I can't stop, since I am already infected, and I just go for them without any fears about [getting] AIDS. (Diston, journal April 13 2001)

The dominant theme that emerges in these assertions of being HIV-positive is travel and mobility. Men who thought they had contracted HIV usually referenced their activities away from home rather than their sexual involvements with local women, even local women who were thought to have HIV. Malawi has for generations been a labour reserve, from which young men go out to work or trade in surrounding countries, and many of the young men in the journals had worked or traveled in Zimbabwe, Botswana or South Africa, all countries with higher HIV rates than Malawi.

In Malawian cultural history, labour migration has for generations been associated with masculinity and with the passage to manhood, as young men seek their fortune in the outside world and, ideally, return with their spoils to the envy of their rural relatives (Chirwa 1992). "Theba" (the local name for labour migration) was associated with particularly masculine forms of power - being able to get a wife and get married, opening a bar or a small business, and the power to excite envy in those who stayed behind through one's knowledge of styles in clothing, language and music in the outside world. For men, Chirwa asserts, theba was "the high road to capital accumulation" (432) (Note 10). The persistent association between manliness, mobility, sexual adventures and HIV has come to make epidemiological as well as cultural sense, as the transport routes in southern Africa are the arteries along which HIV appears to spread. Young men often chatted about travel in conversational groups.

Osman said that he has no doubts he has HIV. He said himself that after coming [back] from Johannesburg he had a TV and after selling [it] he had almost 17000 kwacha [Malawian currency, approximately \$US 200], and the girls were after him, those beautiful ones. (Simon, journal July 23 2000).

Andrew jokingly said that any woman who flirts with him is only digging her own grave, because as he has traveled widely, he is sure of having HIV, since he has been sleeping with different women in all the places he has traveled. To me, the issue carried weight when he told me that he has been to Zimbabwe, Mozambique and Zambia when he was a truck-driver, because I know that in a country like Zambia and Zimbabwe, it's risky, since most women depend on sex for business. (Diston, journal February 19 2000).

"I should tell you the truth, I have slept with many partners and indeed I have to confess, that if it is the case of AIDS I believe I have it even if I did not go for a 
blood test, I just assume that because the time I was going to South Africa I had great luck sleeping with some of the pretty young girls. I had been dreaming about them even when I was in South Africa and some are married women, particularly those married to the so- called bosses of shops, and I had been given money by them sometimes.' We laughed. And he continued saying 'You said the truth that everyone has what pleases him, for example I don't like beer but I like going for ladies.' (Simon, journal June 5 2002).

In additional to having the ring of epidemiological truth, mobility and travel are significant symbols in talking about HIV risk. Sleeping with many partners is referred to as "moving around", and a promiscuous person is referred to by the neologism "movious". Someone, usually a woman, who remains faithful to one partner or who is celibate when that partner is away is said to be "just staying". It is also worth noting that the metaphors which two of the young men quoted below use to describe their numbers of partners also involve travel and transport - the women they have slept with are enough to fill a bus (or two), rather than enough to fill a football field, a school or another large space.

\section{HIV-positive status and masculinity}

Among the young men in the journals, claims to HIV-positive status are not necessarily expressed as despair or grief. Married men, in one-on-one conversations with intimates, may express intense regret over their own behaviour with its implications of orphanhood for their children. For instance, one man who had had an encounter with a prostitute when going to buy fish in Mangochi confided to Sophie:

I have many children and some of them are little. So if I and my wife die with AIDS, who will take care of our many children? Oh, that's why I have become afraid of sleeping with a prostitute, and I confess that it was my first and last time, I will never do that again. And I don't want my wife to know that one time I did such a thing. So that's why I have told you to please not tell my wife about this (Sophie, journal June 17, 2001).

However, in the more public settings of the market or the beerhall, talk about AIDS risk is not nearly so somber. Being HIV-positive can imply a sort of masculine prowess in being a lady-killer (quite literally). In many of the accounts of believing oneself to be HIV-positive, a note of boasting about the sheer number of one's sexual partners often creeps in: 
[Concerning HIV] then it means I have it because in my life I have slept with many girls that whenever I try to take them in total [count them all up] and make them board the bus such as the Zasintha bus, which is the big one, [the girlfriends] can occupy it fully and a half of [a second bus] as well.(Simon, journal June 12 2002).

I have never even tried to use [condoms]. I have slept with many girls and if it is the cause of AIDS then I have already got it because the girls with which I had been having sex, gathering them all could fill a Yanu-Yanu bus. Were they all safe? Then why be using condoms when I prefer not using? (Simon, journal June 7 2001).

Serostatus, in the form of boasts about being HIV-positive, may actually be becoming a marker of virility among these men (Note 11). While wasting away or dying from AIDS-related illnesses is unlikely to ever become a status symbol for men, the status of the behaviour that led to AIDS is more ambiguous, given the link between sexual conquest and masculinity (Note 12). The fact that these young men are claiming to be HIV-positive indicates a significant fissure in the way HIV is conceptualized in Malawi: for some, it is a marker of shame and sin, for others, however, it may signify something different.

The behaviours associated with HIV - having many sexual partners and not using condoms - are also associated with masculinity. Safer sex behaviours, in contrast, are not. Men in the journals tell stories about condoms to approving audiences, describing how they tricked their sexual partners into thinking that the men were wearing condoms when they weren't, or how they lied about using condoms with "hit and run" (casual) partners in order to placate long-term wives or girlfriends. Skin-to-skin ejaculation is the marker of a real man - one who uses condoms is being cheated out of his right to a high-grade sexual experience, or may even be the subject of gossip or ridicule. One of Simon's friends claimed that he would never use condoms with his casual partners because to do so would cast aspersions on his manliness:

[It is] better that I ejaculate inside them, so that the girl should understand that indeed I am a man and avoid underrating [ridiculing] me - because if you don't ejaculate in her, girls are great gossips and you may hear about that issue somewhere else. The girls may spread the news and be talking about you everywhere, and a lot of zibwenzi [casual sexual partnering] ends because of this, when a man insists on using Chishango [local condom brand]. 
The following quote brings together several of the themes touched on above mobility, status, masculinity and HIV. While chatting in a small marketplace near the main road, one young man begins boasting about his brother, and how his brother will come back from South Africa with money and luxury goods to distribute to the stay-athomes. As a result of his exploits, he will be able to sleep with any woman he wants, unlike the local boys. Stung by this, one of his companions retorts that he himself has slept with all the girls that the brother wants, and therefore, if anybody is going to be the cause of an AIDS outbreak in the village, it will be the local boy and not the braggart from the city.

A young brother of this man who went to South Africa ... started boasting,

"My brother today he is having his passport renewed and probably tomorrow as his plan [he will be] be going to South Africa and [coming] back in December 2001. And he said this time he will bring more goods, TV's, car cells/batteries and he will want to have his house roofed with iron sheets. I have to propose [sex to] Mary for him [so that] when he is coming back he should be enjoying [sex] with her. I know Mary won't refuse for she definitely knows that my brother has a lot of money in cash and even in the bank, and [every time he goes to] he has in South Africa [he has] a great amount of money in terms of Malawi currency. The women he has slept with are the beautiful ones - even you, Phiri, you have never slept with them though you claim to have a lot of money." (Phiri is the young brother of [the owner of] a successful rural store).

Phiri said, "You don't know [that] I have slept with all beautiful young girls here within [the neighbourhood], he is just following in my footprints (he meaning Russell, the one going to South Africa). He is going after the ones who I have already gone with. You ask who? Like Khadija? Khadija Banda I have slept with her for so long and I dropped her because I was fed up with her. Like Susan, like Abiti James, I have slept with them all. And if I have AIDS then Russell has also it, I have given him HIV via these girls and don't be so proud, he is going to die soon. He has gotten AIDS from the girls and how is he going to prosper?"

And we were laughing. And the young brother of Russell said, "You have AIDS?" And Phiri said, "Yes, I have it, even your brother also has it for I gave it to him." (Simon, 10 ${ }^{\text {th }}$ journal received, June 2002). 


\section{Serostatus belief and sexual behaviour}

This relationship between HIV, sexual conquest, status and mobility suggests that ideas about masculinity among young Malawian men are being reconfigured in the process of talking about the epidemic. In social-psychological terms this is a fascinating insight into gender transformations, but in public health terms what is of more consequences is the way that beliefs about being HIV-positive are used to justify high-risk sexual behaviour. The professed belief that one already has HIV gives young men another reason not to use condoms or limit numbers of partners - if the virus has already gotten them, what's the point in foregoing future enjoyment by using a condom or passing up chances for sex? If one truly has AIDS, sex may be one's last pleasure. As one of Simon's friends put it, if he knew he had AIDS, he would see "no need to stop doing sex, but rather continue doing it until [we] two are so sick with the disease that we cannot do the exercise" (Simon, $6^{\text {th }}$ journal, June 2002). The same friend also punned on the well-known advice that HIV-positive people should eat a balanced diet in order to ward off infections, and said that if he had HIV, he would indeed want to "balance his diet" by having sex with diverse women, most of whom he assumed would also be HIV-positive (ibid). Some men claimed that they were already doing exactly that. They say that they will "continue on with affairs", and not bother with condoms, because "I know I am already infected". Other young men talk about sex and lust for attractive women as a powerful force which is almost impossible for a man to resist - and indeed, why resist if resistance will not protect you from anything? (see Kaler 2002).

The link between a particular mindset concerning one's serostatus and a particular set of sexual behaviours is very hard to establish, however, largely because men's beliefs about their serostatus appear to shift from time to time and place to place. It is impossible to say for certain what a man really believes about his own serostatus, without access to his innermost thoughts, which no data collection method short of telepathy can provide. Indeed, the idea that there is a fixed, unchanging belief about one's serostatus, analogous to a fixed unchanging belief about the colour of one's hair, is not supported in the journals. Men may make different claims in different settings, they may claim that they know they are going to die one moment and then talk about adopting preventive measures the next.

The excerpt below exemplifies the shifting, unstable nature of claims about one's serostatus. The incident involves a group of young men hanging around at the local market. One of them, Livingstone, announces that he has changed his ways in light of the AIDS epidemic, he used to have many partners but now he is "selective" (presumably in order to avoid losing his HIV negativity). Yet a moment later, he announces that he thinks he must be HIV-positive, because of the number of girlfriends he has had (and invoking the mobility metaphor of the bus once again). Later still in the 
conversation, Livingstone and his friends depart, leaving the journalist alone with one of Livingstone's friends, Peter, who says that Livingstone is a liar. He has not changed his ways, according to the friend, he still has sex with whomever he can persuade or coerce, unlike who claims to follow a different model of sexual behaviour. Peter is sure that Livingstone must have HIV.

Livingstone said, 'I am indeed now grown up - but the fact is not long ago I was troubling women a lot. I could not just see a woman like that one and just leave her like that without following her until I slept with her (he laughed). Because nowadays there are more diseases which have come, including AIDS, it seems I have lowered my pulse [decreased my sexual interest].'

Emmerson said, 'Livingstone, you have to tell the truth! Are you really afraid of AIDS?' (Emmerson is a best friend to Livingstone).

And Livingstone said, 'Ooh! Yes. I am very concerned about AIDS nowadays, [much more] than before. Even though I go for sexual partners, I go with timing (he said 'timing' in English, I think meaning 'with much awareness.')

And I asked, 'What kind of timing are you saying, friend?'

And Livingstone said 'Timing in terms of selecting.'

Emmerson said, 'Indeed Livingstone, I can assure you that in terms of selecting, you were the hero. You were going with beautiful ladies indeed. Martha, both Marthas, that's Martha Nsondole and Martha Chupa, etc."...Then the talk went on, to the point of Livingstone saying that he (Livingstone) is in the group of people who assume they themselves have the disease (he said this himself cheerfully, and with no sign of concern), and he went on saying that he had slept with so many girls that if one tried to make them board a bus you would need the Zasintha bus. ... [After Livingstone and Emmerson have gone for a walk] Peter said, 'I prevent it [getting HIV] by not having many partners. I only have this one and after ending this partnership I will go for someone else and this time only one partner [at a time] as well. In addition, I don't do rape [referring to aggressive male sexuality in general, not only criminal rape] as these friends do (meaning Felesi, Livingstone and Emmerson who had just gone inside the market for a walk). Livingstone was lying to you [when he said] that he had stopped raping and says he's afraid of AIDS.'

I said Livingstone said that, and also that he assumes he has AIDS.

Peter said, 'He is a liar, Livingstone goes for raping, in December 2001 he raped a certain beautiful middle-aged woman from Zambia who was totally drunk on kachaso [strong home-brewed alcohol]. He was also drunk, he followed her and raped her. The case was known to the chief, for a lady cried out and people came. Livingstone lied to them saying they agreed to have sex, and because both of them 
were drunk the people who had gathered believed him. And that he has AIDS, I believe he has indeed, even though I am not a doctor. But you heard yourself that even a Zasintha bus can be filled by the ladies with whom he has slept-plain [no condom] always.' (Simon, journal June 13 2002).

\section{Conclusions}

From this paper, I draw several conclusions. First, the relationship between HIV risk and masculinity is more complex than has previously been thought. Other observers have made the link between masculinity and high-risk behaviour, especially in the context of recurrent labour migrations (e.g. Campbell 2000, Campbell 1997, Hunt 1989, Moodie 1994, Packard and Coetzee 1995, Dodoo 1998, Setel 1999, Bond and Dover 1997). The existing work suggests that concepts and markers of masculinity are the background against which high-risk behaviours are played out, thereby accelerating the epidemic. However, this present study suggests masculinity itself is being transformed by the AIDS epidemic, as HIV status is incorporated into ideas about what real manliness involves. Claims to be HIV-positive have become currency in the boasting games through which men brag about their status vis a vis other men, as these claims underline the quantity and quality of the sex one has had. Actually having AIDS has not become a desirable thing among Malawian men, but the evidence in this paper points to an ongoing reconfiguration of masculinity and an incorporation of the AIDS epidemic, under certain conditions, into masculine status formation. Given the relative homogeneity of masculinity scripts around the world, with emphasis on both heterosexual activity and taking risks, I doubt that these Malawian men are unique.

In addition to shedding light on new formulations of masculinity, this paper also demonstrates the diverse meanings of HIV in Malawian communities. Most research on how people think about AIDS has focused on formulations of stigma, and denial. The evidence in this paper does not challenge these formulations but highlights the fact that the connotations of AIDS are highly context-dependent. In many settings, AIDS is indeed associated with shame and guilt (Note 14). However, in other contexts such as male homosocial groups, the virus may take on different meanings altogether.

Third, the fact that so many men claim that they are HIV-positive, and more importantly that they appear to use this belief as a justification for continued unsafe sex has major implications for future research and for HIV prevention education. Men's claims to have HIV should be read in the light of quantitative findings from similar settings, in which people who claimed to be HIV-positive actually were not. For example, Kengeya-Kayondo et al (1999) found that among Ugandan men who said that they believed themselves to be HIV-positive, only $32 \%$ actually were, based on blood 
tests. In a social climate in which AIDS is assumed to be highly infectious and in which the sentiment that "everyone has AIDS now" is frequently heard, it is not surprising that some men may assume that they already have HIV, presenting a major challenge for IEC and behaviour change campaigns.

One way to meet this challenge might be for educational campaigns to point out that HIV infectivity is not as high as supposed, and thus even though a person may have engaged in high-risk behaviour, the odds are still good that he or she is still HIV negative and thus can still save him or herself from death by AIDS. However, given the human capacity for finding justifications for doing what one wants, such a campaign runs the risk of being interpreted as saying that HIV is not really that dangerous, and so the need for condoms and restraint is overblown. From an HIV prevention standpoint, the ideal mindset may be that of the person who believes he is HIV-negative but also believes that his next sexual encounter without a condom will give him HIV. Encouraging this mindset, though, is much easier said than done. One possible theme which could be taken up in IEC is the risk of reinfection for HIV-positive individuals who have unprotected sex with other HIV-positive individuals. Although the exact nature and consequences of reinfection are debated, educational material highlighting the prospects of reinfection might at least give men who believe themselves, rightly or wrongly, to be HIV-positive a reason to use condoms (Kamya 1998 gives reason to think that emphasizing the dangers of reinfection may lead to condom use in HIVpositive men; see also Were and Kiirya 1998). Along the same lines, this paper may offer tentative support for the expansion of voluntary counseling and testing programmes. If we assume that many Malawians who think they are HIV-positive may actually be negative, then it is possible that learning the truth about their serostatus may encourage them to change their behaviour.

Men and masculinity have come under the lens in this paper, thanks to the journalists' unique access to what men say and do beyond the gaze of surveys, questionnaires and the standard equipment of demographic research. "Typical male behaviour" is implicated in the transmission of HIV; at a deeper and more subtle level, so is the concept of masculinity which drives such behaviour, at least in part. Ideas as well as actions concerning HIV are linked to gender identity and in this case are fed by inaccurate beliefs about the virulence and infectivity of HIV. At all levels, ranging from the symbolic to the behavioural to the epidemiological, AIDS is a gendered epidemic. 
Demographic Research - Special Collection 1: Article 11

-- Social Interactions and HIV/AIDS in Rural Africa --

\section{Notes}

1. Work for this paper was supported in part by the Wenner-Gren Foundation. I am grateful for comments by Shelley Clark, Joseph de Graff-Johnson, Francis Dodoo, Nancy Luke, Mike Mtika, Tanya Taylor, Susan Watkins and Eliya Zulu on an earlier draft.

2. See Mtika 2001 for ideas as to why men might talk more about their sexual adventures than women.

3. This rate varies according to the gender of the uninfected partner, the presence or absence of genital ulcers in the uninfected partner, and the viral load of the infected partner (Quinn et al. 2000).

4. Pseudonyms were assigned to the speakers whose words were recorded in the journals in order to preserve their privacy.

5. "Natural discourse" does not imply unmediated discourse. These journals are vulnerable to "speaker bias", as some people within a conversation group will speak up while others, for reasons to do with personal characteristics or social positions, will remain silent and thus unrepresented $\mathrm{n}$ this paper. In addition, these accounts of what people say about AIDS are only that - accounts of what people say, not of what they do to what they intend or even what they believe. We must thus be very careful about extrapolating behaviour from these journals.

6. Or perhaps more accurately, trading the structures and conventions of the interview situation for those of the peer group.

7. I say "voiced" deliberately instead of "heard", because the journals contain silences as well as voices. We do not know the views or experiences of those who don't speak up in public; we do not know the extent to which conversation settings silence some participants even as they facilitate the voices of others.

8. See also Kaler 2002.

9. Indeed, as I argue below, living up to, or down to, the types of behaviour depicted in AIDS educational materials may be a point of pride for some men.

10. In my own interviews with elderly Malawians in 1999 and 2001, for many of them, going out to work in the 1940s through 1970s marked a personal transition between being considered a boy and being considered a man equal with other men.

11. HIV-positive status, as distinct from the ravages of AIDS, was often associated with high sexual status in general, among women as well as men. Men's comments 
on the most beautiful and desirable women around them often included speculation that the women probably had HIV as a consequence of her sexiness, especially when the woman in question came from town or was observed to be expensively dressed, as no one so beautiful could possibly be sexually inexperienced. Although young men might admire the beautiful, sexy, allegedly HIV+ woman, they "went for" women of lower status who were assumed as a result of their background to be HIV-free. Incorporating HIV-related characteristics into partner choice was the dominant form of behaviour change in the face of HIV (Kaler 2002).

12. See Nioka 2001 for more on STDs in general as markers of masculinity among young men.

13. Clearly, being the transmitter of AIDS is more highly regarded than being the "transmittee". In another account of HIV transmission as a source of male pride, Simon was part of a conversation about HIV at a funeral, during which man opined that "It is painful and very bad to die because of women. It is better that we men should be [catching] disease elsewhere and be giving them [i.e. giving diseases to women] than them giving us" (journal October 6 2001). See Leclerc-Madlala 1997 for an interpretation of claims to transmit HIV as a way of asserting some degree of control over the epidemic.

14. See Chimwaza and Watkins 2002 for details of AIDS stigma in the same district as covered by this paper. 


\section{References}

Bond, V., and P Dover. 1997. Men, women and the trouble with condoms: problems associated with condom use by migrant workers in rural Zambia. Health transition review 7:Suppl., 377-391

Campbell, C. 1997. Migrancy, masculine identities and AIDS: the psychosocial context of HIV transmission on the South African gold mines. Social Science \& Medicine, 45(2): 273-81

Campbell, C. 2000, 'Selling Sex in the Times of AIDS: the Psycho-social context of condom use by sex workers on a South African mine'. Social Science and Medicine, Vol. 50, pp. 479-494.

Chimwaza, AF and SC Watkins. 2002. Giving care to people with symptoms of AIDS in rural sub-Saharan Africa. University of Pennsylvania: Mimeo

Dodoo, F. 1998. AIDS-related condom use among married Kenyan men (Working paper 8). Nairobi: African Population Policy Research Centre Working Papers

Du Guerny, J and Sjoberg E. 1999. Interrelationships between gender relations and the HIV/AIDS epidemic: some considerations for policy and programs. Pp.202-215 in J Mann, S Gruskin, M Grodin and G Annas eds., Health and human rights: a reader. London: Routledge

Farmer, Paul (1994) AIDS-talk and the constitution of cultural models. Social science and medicine 38:6, 801-809

Farmer, Paul. 1999. Infections and inequalities: the modern plagues. Berkeley: University of California Press.

Farmer, P, Connors M and Simmons J (eds.), 1996. Women, poverty and AIDS: sex, drugs and structural violence. Boston: Common Cause Press

Gray RH et al. 2001. Probability of HIV-1 transmission per coital act in monogamous, heterosexual, HIV-1-discordant couples in Rakai, Uganda. Lancet 357(9263): 1149-1153.

Hollander, D. 2001. Risk of HIV transmission is raised by high viral load, presence of genital ulcers. International Family Planning Perspectives September 2001

Kaler, Amy. 2002. AIDS-talk in everyday life: HIV/AIDS in men's informal conversation in southern Malawi 1999-2002. Paper presented at meetings of Canadian Population Society, Toronto July 2002 
Kamya MJ. 1998. HIV/AIDS counselling in Butego Community of Masaka District from 1993 to date. International Conference on AIDS 12: 170

Kengeya-Kayondo, J., Carpenter LM, Kintu PM, Nabaitu J, Pool R and Whitworth J. 1999. Risk perception and HIV-1 prevalence in 15000 adults in rural south-west Uganda. AIDS 13:2295-2302.

LeClerc-Madlala S. 1997. Infect one, infect all: Zulu youth response to the AIDS epidemic in South Africa. Medical Anthropology. 1997;17:363-380.

Mtika, Mike Mathambo (2000) Habits of the heart and the age/sex distribution of the Acquired Immune Deficiency Syndrome in Malawi. Mimeo, University of Pennsylvania, Population Studies Center

Mughogho O. 1998. Window period and its implications in HIV antibody testing. International Conference on AIDS, 12: 1033

Nzioka, C. 2001 Perspectives of adolescent boys on the risks of unwanted pregnancy and sexually transmitted infections: Kenya. Reproductive Health Matters, 9(17): 108-17

Quinn TC, Wawer MJ, Sewankambo N. 2000. Viral Load and Heterosexual Transmission of Human Immunodeficiency Virus Type 1, New England Journal of Medicine 342:921-929

Renaud, ML. 1997. Women at the crossroads: a prostitute community's response to AIDS in urban Senegal. Amsterdam: Gordon and Breach

Schneider, B and Stoller, N. 1996. Women resisting AIDS: feminist strategies of empowerment. Philadelphia: Temple University Press

Setel, P. 1999. A plague of paradoxes: AIDS, culture and demography in northern Tanzania. Chicago: University of Chicago Press.

Tawfik, Linda. 2003. Soap, Sweetness and Revenge: Patterns of Sexual Onset and Partnerships Amidst AIDS in Rural Southern Malawi. Ph D dissertation, Bloomberg School of Public Health, Johns Hopkins University, Baltimore

Tawfik, Linda and Susan Watkins. 2003. Sex in Geneva, sex in Lilongwe, sex in Balaka. Paper presented at the annual meetings of the Population Association of America, Minneapolis, May 2003

Wallman, Sandra. 1996. Kampala women getting by: well-being in the time of AIDS. London: James Currey 
Watkins, Susan C., Eliya M Zulu, Hans Peter Kohler and Jere Behrman. 2003. "Introduction". Demographic Research - Special Collection 1: "Social Interactions and HIV/AIDS in Rural Africa", edited by Susan Watkins, Eliya M. Zulu, Jere Behrman, and Hans-Peter Kohler. http://www.demographicresearch.org

Weinreb, Alexander A., and Henry V. Doctor (2002) Mortality among married men in rural Kenya and Malawi: a life table analysis. Population Research Center, University of Chicago

Were BN; Kiirya SK. 1998. Awareness, perceptions and inhibiting issues of positive living among HIV-infected individuals in Uganda. International Conference on AIDS 12: 914-5

World Bank. 1999. Confronting AIDS: Public priorities in a global epidemic. Washington DC: World Bank 